\title{
THE RELIGION OF NO RELIGION: JUNG'S PSYCHOLOGY IN THE HISTORY OF ZEN BUDDHISM IN THE 20TH CENTURY
}

OLIVER KNOX

PHANÊS • VOLUME $4 \cdot 2021 \cdot$ PP. 51-81

https://doi.org/10.32724/phanes.2021.knox 


\begin{abstract}
ABSRACT
In the 1930s, Zen Buddhism was hardly known outside Japan. By the 1960s, it had become by far the most popular form of Buddhism in Europe and the United States. Its popularity was born from the general belief that Zen responded to the psychological and religious needs of the individual without incurring the criticisms customarily levelled against religion. Zen was imagined as a practical spirituality that accepted all religions and religious symbols as expressions of a universal psychological truth. Zen was not itself a religion, but a 'super-religion' that had understood the inner mechanics of the psyche's natural religion-making function. Three authors in particular, namely D. T. Suzuki, Friedrich Spiegelberg and Alan Watts, were pivotal in the formation of this narrative. Using Jung's psychological model as their conceptual basis, they promoted a vision of Zen Buddhism that laid the foundations for the 'Zen Boom' of the 1950s and 60s. This article will examine the pivotal role played by Jung's psychology in the formation of this narrative.
\end{abstract}

\title{
KEYWORDS
}

Zen Buddhism, D. T. Suzuki, Alan Watts, Friedrich Spiegelberg, The Religion of no Religion. 
Tn 1936, Sir Francis Younghusband (1863-1942) founded the World Congress of Faiths in London, which he hoped would bring together experts on the world's major religious traditions. The theme of the conference was entitled 'The Supreme Spiritual Ideal'. The final speaker was Teitaro 'Daisetz' Suzuki (18701966), a Japanese Buddhist scholar and translator of the Lankavatara Sutra. Dr Suzuki's lecture would make an indelible impression on a young man called Alan Watts (1915-1973), then editor of the journal Buddhism in England, who was in the audience that day. Watts remembered the occasion as follows:

After several speakers had delivered themselves of volumes of hot air, Suzuki's turn came to take the platform. "When I was first asked," he said, "to talk about the Supreme Spiritual Ideal, I did not exactly know what to answer. Firstly, I am just a simple-minded countryman from a far away corner of the world suddenly thrust into the midst of this hustling city of London, and I am bewildered and my mind refuses to work in the same way that it does when I am in my own land. Secondly, how can a humble person like myself talk about such a grand thing as the Supreme Spiritual Ideal? ... Really, I don't know what Spiritual is, what Ideal is, and what Supreme Spiritual Ideal is." Whereupon he devoted the rest of his speech to a description of his house and garden in Japan, contrasting it with the life of a great city. This from the translator of the Lankavatara Sutra! And the audience gave him a standing ovation. (Watts 1986:191).

This anecdote exemplifies how Suzuki, who is today known as the most significant Zen scholar of the twentieth century, was received by a generation of twentieth century scholars, intellectuals and artists. Zen, as Suzuki presented it, offered a unique and subversive approach to spiritual questions. It was, strictly speaking, neither a religion nor a philosophy. It gave as little importance to belief, ritual and dogma as it did to rational or existential thinking. Zen, he argued, was, first and foremost, experiential. It cut straight through to the heart of humanity's spiritual yearning. Its essence lay in satori, enlightenment, which he described as the unmediated, direct experience of the eternal present. Although Suzuki 
became by far the most significant Zen scholar of the twentieth century, his portrayal of Zen was in fact typical of a faction of Japanese Zen adepts, who, having become dissatisfied with the rigid style of Zen traditionally practised in Japanese zendos, sought fresh pastures for transmission in Europe and America. ${ }^{1}$ It has been quite convincingly argued by modern scholars that Suzuki's Zen owes more to his Westernised education than to his direct involvement with Zen as traditionally practised in Japan. ${ }^{2}$ Moreover, Suzuki was never formally ordained as a Zen teacher.

\section{JUNG'S ZEN}

In the decades between 1930 and 1960, Suzuki was considered the leading authority on Zen. It was his Essays on Zen Buddhism (1927) that first sparked an interest in Europe. Jung was, at this time, familiar with Suzuki's works, having been sent copies of Essays in Zen Buddhism: First Series, and Second Series, as well as his Training of the Zen Buddhist Monk and Introduction to Zen Buddhism by Suzuki himself. ${ }^{3}$ Jung's study of Zen was complemented by some earlier, more obscure works, which had received relatively little attention in Europe, such as Nukariya Kaiten's The Religion of the Samurai (1919), ${ }^{4}$ as well as Shuei Ohazama's

\footnotetext{
${ }^{1}$ Other contemporary Zen scholars like Nukariya Kaiten (1867-1934) and Yasutani Hakuun Roshi (1885-1973) portrayed Zen in a similar light to Suzuki. Some scholars have argued that the secularised style of Buddhism presented by contemporary Japanese Zen teachers was connected to 19th and 20th century Japanese imperialism. Brian Victoria, for example, has argued that Zen teachers promoted a secularised version of Zen as a form of religious warfare. Zen, he writes, became 'the spiritual vangard of Japanese militarism' (Victoria, 1997:27). He quotes, for example, a passage from a book published by Yasutani Roshi, in which the author writes, 'Annihilating the treachery of the US and Britain in establishing the Greater East Asia Co-prosperity sphere is the only way to save the one billion people of Asia ... we must train and send forth a great number of capable men who will be able to develop and exhalt the culture of our imperial land ...' (1997:61). Yasutani Roshi became well-known through the book The Three Pillars of Zen (1965) by Yasutani's student, Phillip Kapleau (1912-2004), one of the first instructional books on Zen meditation published in English.

${ }^{2}$ According to Zen scholar Robert Scharf, Classical Zen in fact 'ranks amongst the most ritualistic forms of Buddhist monasticism' (Scharf, 1993:1). For more information on the formation of Suzuki's idiosyncratic presentation of Zen, see R. Scharf's The Zen of Japanese Nationalism (1993) and R. Fields, How the Swans Came to the Lake (1981).

3 Copies of Suzuki's works can be found in Jung's personal library.

${ }^{4}$ Kaiten was a professor at Harvard, and a close friend of Suzuki. This book was one of the first books on Zen published in the West. Kaiten's interpretations of Zen have been criticized for his tendency to fit Zen into Western concepts and its undertones of Japanese militaristic nationalism.
} 
Der Lebendige Buddhismus in Japan (1925), to which Rudolf Otto had contributed a foreword. ${ }^{5}$ Yet Jung considered Suzuki's works 'among the best contributions to the knowledge of living Buddhism that recent decades have produced', and Zen itself to be 'the most important fruit to have sprung from the tree whose roots are the collections of the Pali Canon' (Jung 1939: 538). ${ }^{6}$

Suzuki's works often describe typical Zen experiences, coating them in Western psychological terminology. ${ }^{7}$ Intrigued by the apparent parallels between Suzuki's accounts of Zen experiences and his own psychology, Jung agreed to contribute a foreword to Suzuki's Introduction to Zen Buddhism (1939), in which he provided a psychological interpretation of koan practice. ${ }^{8}$ The koan was, he supposed, an instrument for the Zen adept to bypass the rational intellect, creating 'an almost perfect lack of conscious presuppositions' (Jung 1939:549). This laid the ground for a suspension of consciousness, which in turn gave rise to a psychic vacuum into which contents of the unconscious could emerge. He wrote,

What the unconscious nature of the pupil presents to the teacher or to the koan by way of answer is, manifestly, satori. This seems, at least to me, to be the view which, to judge by the descriptions, formulates the nature of satori more or less correctly. It is also supported by the fact that the 'glimpse into one's own nature,' the 'original man,' and the depths of one's being are often a matter of supreme concern to the Zen master. (Jung 1939: 549).

The idea of suspending consciousness in order to allow contents to emerge from the unconscious was a technique Jung was familiar with from his self-experimentations between 1913 and 1932, recorded in the

\footnotetext{
${ }^{5}$ Otto was one of the first Westerners to visit Zen monasteries in Japan and converse with Zen Masters.

6 In a letter to Suzuki, dated 22 September, 1933, Jung thanks Suzuki for sending him a copy of his Essays in Zen: Second Series, saying, 'I am a very great admirer of your former work on Zen'.

${ }^{7}$ For instance, in Essays on Zen, he wrote that 'Zen consciousness ... (is) a glimpse into the unconscious' (Suzuki 1934:46).

${ }^{8}$ A koan refers to short questions or statements made by Zen Masters to test a student's progress in Zen. The aim of the koan is to lead the student to kensho, into insight into one's own 'Buddha-nature'. For Suzuki, satori follows from understanding the koan. Interestingly, Scharf (1993) claims that in traditional Japanese Zen, koan practice is far more a traditional ritualistic procedure than a way of achieving satori.
} 
Black Books. ${ }^{9}$ Jung referred to his procedure, as Shamdasani notes, in his dream book on April 17, 1917, as 'frequent exercises in the emptying of consciousness' (Shamdasani 2020:24). Still earlier, Jung had practised a similar suspension of the intellect on his patients during his word association experiments with Riklin in 1904. Here, the experimenters used hypnosis, suggestion and distraction as ways of circumventing the conscious attention of their subjects, thereby inducing responses indicative of unconscious associations. ${ }^{10}$ Jung understood koan practice as having a similar intention, namely the induction of an increased flow of libidinal energy into the unconscious. ${ }^{11}$ He claimed that such constriction of conscious contents would necessarily entail on overflow of psychic energy into the unconscious. 'In Zen', he adds, 'this displacement usually results from the energy being withdrawn from conscious contents and transferred either to the concept of "emptiness"12 or to the koan' (Jung 1939:551). Excess energy eventually results in a "damming up" of unconscious contents, which consequently break through into consciousness. Jung noticed a similar process occurred in cases of psychopathology. The difference between satori and psychopathology, he suggested, was simply that the former was the intended result of a long period of training, which allowed meaningful integration of the experience into conscious life, whereas the latter was an involuntary 'invasion' of the unconscious into consciousness. Two decades later, in 1958, during a conversation with Zen Master Hisamatsu (1889-1980) which had been arranged by

\footnotetext{
${ }^{9}$ Later, in his 1938-39 ETH lectures, Jung claimed that Mahayana Buddhists had uncovered the same technique in order to induce visions. Speaking of the effects of Buddhist meditation, he remarked, '... that is the purpose, that emptiness, shunyata, is created and one finally owns nothing any longer' (Jung 1938:95).

${ }^{10}$ Jung's comments on the results of his experiments can be found, among other works from the same period, in his The Association of Normal Subjects (1904).

${ }^{11}$ In his analysis of the Association Experiments, Jung argued that although energy can move between consciousness and the unconscious, it can neither be created nor destroyed. Excess energy on one side will result in a compensatory reduction on the other, and vice versa. This idea is embellished in Jung's On the Energetics of the Soul, in which he contrasts the energic and mechanistic (causal) models of reality. He states what he calls (following Busse), the 'principle of equivalence', which states that 'for a given quantity of energy expended or consumed in bringing about a certain condition, an equal quantity of the same or another form of energy will appear elsewhere' (Jung, 1928:18).

12 In Buddhist soteriology, emptiness (sunyata) refers to the ultimate nature of all phenomena. Jung understood sunyata as a sort of primordial state of being, comparable to the idea of Chaos in alchemy (Jung 1939: 71).
} 
Suzuki, ${ }^{13}$ Jung repeated this conviction. 'The goal in psychotherapy', he remarked, 'is exactly the same as in Buddhism' (Jung 1958:112).

Jung's interest in Buddhism during this period was not limited to Zen. Although he considered Zen 'the most important fruit' of the Pali Canon, Jung published and lectured far more extensively on texts from other Buddhist traditions. ${ }^{14}$ His most extensive treatment of Buddhist texts were his 1938-39 ETH Lecture series, which focused particularly on two texts, the first, called the Amitâyur-Dhyâna-Sûtra, taken from the Pure Land tradition, ${ }^{15}$ and the second, namely the Shrî-chakra-sambhâra Tantra, from the Tantric tradition. ${ }^{16}$ Jung's foreword to Suzuki's Introduction to Zen, however, remained his only extensive publication on Zen Buddhism. ${ }^{17}$ Yet Jung's significance to twentieth-century interpretations of Zen is far greater than the relative scarcity of his own writing on the topic suggests, greater, indeed, than Jung himself imagined. The 'Zen' that became popular in the 1950s and 60s in the United States and Europe was, as we shall see shortly, a synthesis of Suzuki's Zen and Jung's psychology of religion. Two figures in particular were responsible for its construction, namely Frederic Spiegelberg, and Alan W. Watts, both of whose work relied, in equal measure, on their understanding of Jung and Suzuki.

\footnotetext{
13 Suzuki's involvement in the organisation of this meeting can be established from a correspondence between Suzuki and Jung, particularly a letter sent by Suzuki to Jung, dated 12 March 1958, in which Suzuki asks Jung to 'spare a moment for his (Hisamatsu's) interview ... sometime between May 1 -25' (Suzuki letter to Jung, C.G. Jung Papers Collection, ETH Zurich University Archives, HS 1056:25884).

${ }^{14}$ See, for example, his foreword to the Tibetan Book of the Dead (1935) and his commentary on The Tibetan Book of the Great Liberation (1955). Jung also published a foreword to Karl Eugen Neumann's Die Reden Gotamo Buddhos (1956), a collection of speeches of the Buddha.

15 The Pure Land tradition, which first became popular in China in the 4th CE, is charactersied by the belief in a 'Pure Land' (Sukhavati) in which rebirth is desirable, and in which conditions are particularly favourable for practice of the Dharma.

16 Tantric Buddhism refers to a broad class of texts derived from the general framework of Mahayana Buddhism, particularly as set out by Nagarjuna's Madhyamaka ('Middle Way') and the 'idealist' school of Yogacara. Buddhist scholar Rupert Gethin defines Tantra as 'the final development of Indian Buddhism ... giving special emphasis to the idea of the equivalence of nirvana and samsara' (Gethin 1998: 268). For Jung's lectures on these texts, see Jung's Psychology of Yoga and Meditation: Lectures Delivered at ETH Zurich, Volume 6.

${ }^{17}$ Jung makes cursory, yet revealing, references to Zen in various places in his oeuvre; see for example, CW 1938:1290, 1957:68, 1947:225.
} 


\section{FREDERIC SPIEGELBERG}

Frederic Spiegelberg was a German theologian and a professor of comparative religion at the University of Dresden, where he took over Protestant theologian Paul Tillich's teaching position in 1933. Four years later, Tillich helped Spiegelberg escape Hitler's Germany and flee to the United States. There Spiegelberg taught at Columbia University, before joining Stanford as a lecturer in 1941, where he became professor of Indian civilisation in the Department of Asiatic and Slavic Studies, before retiring in 1962. Spiegelberg was an unconventional lecturer whose research interests ranged from Tantra and Tibetan Ghost Traps to western alchemy. He was also an accomplished scholar of several ancient languages including Sanskrit, Pali, Greek and Latin. His lectures at Stanford were often oversubscribed and his magnum opus, entitled The Religion of no Religion (1957) became famous in the American counterculture in the 1950s and 60s, though today it is relatively forgotten.

Spiegelberg and Jung had a long-standing friendship. They first met at a conference in Dresden in 1928, after which Spiegelberg was invited to the Jung Institute, Zurich in 1931. They frequently met at Jung's house in Küsnacht or at the yearly Eranos conferences in Ascona. ${ }^{18}$ Spiegelberg was later invited to the 1932 Kundalini Seminar Series given by Jung together with the Indologist Jakob Hauer (1881-1962) at the Psychological Club in Zurich. ${ }^{19}$ Throughout his career, Spiegelberg frequently gave university lectures on Jungian psychology. ${ }^{20}$ In 1947, for example, Spiegelberg gave a lecture on ' $\mathrm{C}$. G. Jung's recent contributions to the psychology of religion', in which he reported on Jung's then untranslated German works from 1940-1946. ${ }^{21}$ Later, in 1957, Spiegelberg gave a lecture on

${ }^{18}$ The Eranos conferences, starting in 1933, was among the first conferences in Europe to bring together internationally renowned scholars on Eastern religion. The aim of the conferences was to provide a 'meeting-place between East and West' (Hakl 2013:25).

${ }^{19}$ As Shamdasani notes, Jung was initially unsure whether to invite Spiegelberg, remarking in a letter to Hauer in May 1932 that 'other information I have about Dr. Spiegelberg does not sound enthusiastic, hence I would like to ask you if you are keen on this Spiegelberg, who seems to be an intellectual Jew. I have to admit that I am a bit in two minds and that I am fearing for the quality of the atmosphere. However, I want to leave the decision entirely to you since you seem to know Spiegelberg' (Shamdasani 1996:37). Spiegelberg did, however, eventually attend the seminar series, along with his wife. At the time of Jung's letter, the two had only met twice. Jung's relationship with Spiegelberg improved over the following years.

${ }^{20}$ In a letter to Jung, dated 13 January 1947, for example, Spiegelberg writes to Jung discussing some of the content of his lecture topics (Spiegelberg letter to Jung, C.G. Jung Papers Collection, ETH Zurich University Archives, Hs 1056:14016, 1).

${ }^{21}$ Spiegelberg letter to Jung, C.G. Jung Papers Collection, ETH Zurich University 
Jung's recently published Present and Future. ${ }^{22} \mathrm{He}$ also gave addresses at various Analytical Psychology Clubs, including a series of six lectures at the New York Analytical Psychology Club in 1938. Moreover, according to his student James Plaugher, he often invoked Jung's authority during his lectures on Buddhism and eastern philosophies. ${ }^{23}$ Records of his correspondence reveals that Spiegelberg would often ask Jung for suggestions on lecture themes as well as for psychological interpretations of Buddhist iconography from his, Spiegelberg's, vast private collection. ${ }^{24}$ Jung, on the other hand, would often acknowledge Spiegelberg's efforts in popularizing his work in America. Referring, for example, to his lecture on Present and Future (1957), Jung wrote, 'I can imagine that the American audience finds some difficult chunks in my essay. Therefore, I am indebted to you for addressing edifying words to the audience' (1957:1). Spiegelberg also followed Jung's interest in western alchemy, aiding Jung's research by sending him examples of Tibetan mandalas and ghost traps from his private collections. In 1945, now a lecturer at Stanford, Spiegelberg published a work on alchemy, entitled Alchemy as a Way of Salvation (1945), which draws extensively on Jung's work. This close association with Jung's thought would prove vital to Spiegelberg's later ideas on Zen.

\section{ALAN WATTS}

The second significant figure in the construction of a 'new Zen', so to speak, was Alan W. Watts, one of the first interpreters, along with Suzuki, of Zen in the West. Watts began reading Suzuki during his final years at school, where he was considered among the brightest pupils of his day. Despite his reputation, Watts left school a term early, seeing no reason to enrol at university. At seventeen, he was already writings articles for the Buddhist Lodge in London, founded by Christmas Humphreys, ${ }^{25}$ and Archives, Hs 1056:14016, 1.

${ }^{22}$ Spiegleberg letter to Jung, C.G. Jung Papers Collection, ETH Zurich University Archives, Hs 1056:24345, 1.

${ }^{23}$ David Ulansey, The American Academy of Asian Studies. Published in CIIS Archives, 1994.

${ }^{24}$ In 1951, for example, Spiegelberg held a series of public lectures at the American Academy of Asian Studies entitled 'Tibetan Ghost Traps', in which he presented the psychological interpretations that he had discussed with Jung in their correspondence. Spiegelberg sent Jung a Tibetan Buddhist mandala for interpretation which his 'Tibetological friends seem unable to explain' (Spiegelberg 1947:1).

${ }^{25}$ Humphreys was a member of the Theosophical Society. Despite his admiration for Humphreys, Watts was unimpressed by Humphreys's Theosophical inclinations. 
soon became the editor of their monthly magazine, Buddhism in England. He had already published a booklet on Zen, largely derivative from Suzuki's work. He attended, in his words, his own 'private university' at the Buddhist Lodge, where he read 'all the literature which was "oddball" and screened out of the curriculum', (Watts 1972:100), including Jung.

Watts studied Jung's works intensely and continued to do so throughout his career. Between 1936 and 1961, Watts's general psychological and comparative approach to the study of religion derived from his reading of Jung. In his autobiography, he wrote,

Anyone who has read my books from The Legacy of Asia [1937] to Psychotherapy East and West [1961] will see what a vast influence Jung has had on my work, and how my enthusiasm for Oriental wisdom has been disciplined by his celebrated commentary on Richard Wilhelm's translation of The Secret of the Golden Flower. Over those years I read everything Jung wrote as soon as it was translated, including many of the privately circulated volumes of the transcriptions of his seminars, in which he could speak freely without fear for his scientific reputation as a physician, and thus go deeply into such disreputable subjects as astrology, alchemy, and kundalini yoga. (1972:313).

In one of his early works, The Legacy of Asia and Western Man (1936), written when he was only twenty-one and which he later called 'a somewhat immature book', Watts attempted to relate Eastern thought and mysticism to Jung's psychology. The book 'owed its inspiration', Watts wrote, to Jung's commentary to The Secret of the Golden Flower. For Watts, it was Jung who had opened up a way of understanding the East 'that did not involve breaking away from our roots ... by approaching Eastern wisdom neither as outworn superstition, nor as metaphysics, nor as a body of esoteric and inaccessible mysteries, but as psychology' (1936:xiv). Watts was particularly attracted by two aspects of Jung's thought. First, Jung had, in Watts's view, reformulated the practice of psychotherapy by shifting its focus from the cure of pathology towards higher spiritual development. Second, Jung was the first psychologist to consider the study of religion, particularly Eastern religion, of critical importance to the study of psychology.

In 1939, Spiegelberg suggested that Watts give a lecture at the New 
York Jungian Analytical Psychology Club. The same year the Club invited Watts to present his lecture, entitled The Psychology of Acceptance, which was subsequently published in mimeograph. A year later, Watts expanded his lecture into a book entitled, The Meaning of Happiness: The Quest for Freedom of the Spirit in Modern Psychology and in the Wisdom of the East. By this time, Watts had established a regular correspondence with Suzuki, who had given him a number of insights into new ways he had of presenting Zen to the West (Watts 2017:51). Watts used Jung's concept of individuation as the guiding principle of his lectures, and, in front of an audience of Jungian analysts, advocated the necessity of a rapprochement between eastern philosophy and western psychology. Echoing Spiegelberg, Watts claimed that whereas in the west psychology was a new science, in the east it was very ancient:

We must learn, however, to concentrate on the psychology of Oriental religion as distinct from its metaphysics. In fact, it is very doubtful whether its metaphysics was ever intended to be taken as metaphysics. For Oriental philosophy is emphatically not philosophy in the Western sense of the word, having scarcely any relation to the intellectual search for objective, metaphysical truth which we find in Descartes, Berkeley, Hegel, and other Western metaphysicians. Thus the Oriental doctrine of the union of man and Brahman is the symbol of a psychological experience rather than a statement of objective fact, and it is almost impossible to study Oriental religion with profit unless one is always careful to inquire into the experience behind the doctrine. (Watts 1940:82).

The theme of his book, he argued, was the realisation of happiness in the Aristotelian and Thomistic sense of man's true end or destiny, in which happiness means union with the divine, or the Dao or nirvana. Watts addressed the question concerning what western and eastern psychology, taken together, could tell us about the nature of human happiness. 'As we have seen', he wrote, 'Oriental wisdom is psychology rather than philosophy and theology, and the schools of Freud and Jung are the only practical forms of western psychology which have any relation to it... their method is empirical and its aim is to heal and give happiness of the deepest and most abiding kind. This too may be said of Oriental psychology, for the experience or state of mind at which it aims is a conscious harmony with life and nature' (1940:xvii). The 
psychology of the east, he continued, like psychoanalysis, aimed at mental balance through becoming conscious of the limitations of the ego and understanding its relation to the unconscious. 'This is strikingly similar', he concluded, 'to many Oriental teachings if we can substitute for the term "unconscious" such terms as Dao, Brahman and the like, which mean the (to us) unknown self of both man and life, or nature' (1940:xv).

Over the course of his career, Watts remained actively involved in Jungian circles. He gave regular lectures at various Analytical Psychological Clubs and maintained close friendships with some of Jung's principal students, including Helton Godwin Baynes, Charles Taylor, Michael Fordham and Joseph Henderson, and other leading students of Jung (Watts 1972:313). In 1958, after giving a lecture at the Zurich Analytical Psychology Club, he was invited to Küsnacht, where he and Jung spent several hours by the lake talking about various subjects, ranging from the state of contemporary psychology, the mating rituals of ducks, to the similarity between Jung's personal experiences and mystical experiences reported in Buddhist texts. Jung was aware of Watts's work and a copy of The Legacy of Asia can be found in his private library. Several months before Jung's trip to India in December 1937, Watts had written to Jung, asking him to contribute a foreword to it. Jung was in complimentary terms about his work but said that he did not have time at that moment to do it justice:

I like (the book) because it is very intelligently written and it is different from the usual kind of literature on this subject, in so far as you are not blind to the fact that our western civilisation has an inescapable history... Under ordinary circumstances I probably would have written a preface to your book but under the actual circumstances it would be an unforgivable light-heartedness to promise you something I most certainly could not live up to.... But I think your book will make its way without my preface to it. (Jung 1937:1).

Two years later, Watts would ask Jung for permission to use a series of privately circulated seminar notes held by some of his friends at the New York Analytical Psychology Club. Jung's reply was affirmative, and again he praised The Legacy of Asia:

I have been very interested in your book. I think it is a 
most excellent attempt at assimilating Eastern values... You succeeded to avoid the usual theosophic pitfalls, which is a rare quality in such attempts as yours. (Jung 1939:1).

\section{THE RELIGION OF NO RELIGION}

It was, then, Jung who opened the door, for both Spiegelberg and Watts, the the new psychological understanding of religion that determined their later portrayal of Zen Buddhism. Watts and Spiegelberg met in 1936, at the home of Eric Graham Howe, ${ }^{26}$ a psychoanalyst and member of the London Tavistock Clinic. Two years later, Watts published a short essay by Spiegelberg in Buddhism in England entitled The Religion of no Religion. A decade later, Spiegelberg, again with Watts's help, published two books by the same name in 1948 and 1952 which expanded the ideas he had made in his earlier 1938 essay. The Religion of no Religion was Spiegelberg's magnum opus, becoming infamous in the countercultural scene in North America. For Watts, it became a central concept in his own oeuvre from 1936 onwards. It was of particular importance, as we shall see, to their interpretation of Zen.

The Religion of no Religion was neither a religious movement, nor secularism, not even atheism. It was Spiegelberg's implicit theory of the religious imagination, a kind of unconscious operating system, which different figures and communities had expressed over the course of history. He argued that the forms, symbols and rituals of religion were expressions of the original visionary experiences of their founders. Insofar as a symbol can be called 'religious', he claimed, it must necessarily point to the unity of man and cosmos. With the passing of time, however, symbols become 'outworn' and inevitably fail to adequately convey the perennial experience to which they point. Consequently, they become psychologically inefficacious and are overthrown, giving rise to 'new names and forms for God'. The Religion of no Religion was Spiegelberg's attempt to postulate a theory

\footnotetext{
${ }^{26}$ Howe joined the Tavistock Clinic in 1928 and was the author of Motives and Mechanisms of the Mind (1930), War Dance: A Study of the Psychology of War (1939) and Cure or Heal (1965), to which his lifelong friend, R. D. Laing wrote a foreword. Howe was a mutual friend of Watts and Spiegelberg and would often hold informal seminars at his home in London. His particular interest lay in synthesising eastern spiritual philosophies, Buddhism in particular, with western psychotherapeutic practices. It is interesting to note that, though he is largely forgotten, many concepts he pioneered, including the concept of 'radical acceptance' are today mainstream therapeutic techniques. For more information on Howe, see Ian Charles Edwards' Truth as Relationship: The Psychology of E. Graham Howe (2006).
} 
of the cyclical birth and decay of religious symbolic forms. As he put it:

\begin{abstract}
Whenever a generation of mankind has sought for symbols or names of that great power which lies behind all striving, and has succeeded in formulating its idea of God, the next generations will certainly repeat those names again and again, until they are quite worn out, like old coins which are passed from one hand to another-without much reflection - until at last nobody can read the text written on them. They are often still current centuries later, but they have no real meaning, and there will come a day when people will become aware of their meaninglessness and abolish them. Such people would rather live without any names and ideas of God than have outworn and false names. (Spiegelberg 1948:21).
\end{abstract}

The regeneration of religious forms and symbols, Spiegelberg argued, always begins with the recognition of the relative meaninglessness of old 'names and ideas of God' (1948:21). Spiegelberg experienced this meaninglessness first-hand in 1917, when, still a theology student, he took a walk in some wheat fields after reading some verses of Rilke. Suddenly, his 'usual, everyday consciousness vanished', and instead he felt 'something deep, something holy ... his higher Self ... (he) feels in the so-called world nothing but holiness'. While enjoying this transformed reality, he suddenly approached around the corner of the road. A church. The sight of the church gave him a shock. 'What on earth is a church doing in his glorified world?' he wondered, 'what can be behind these stone walls, what means this coloured light behind the windows, and what these strange sounds of music ... All the world around has been holy, has been God's eternal nature, His face and His expression ... if there is really anything else, anything peculiar behind those walls, it could only be a matter outside God, in contrast with, or even in opposition to, this eternal bliss of the all-penetrating holiness' (1948:18).

Such an experience, Spiegelberg argued, always points to the start of a new cycle of religious forms. The experience of the relative meaninglessness of religious symbols, in fact, revivifies the religious imagination. It creates accumulation of energy in the unconscious, activating images lying dormant in the collective unconscious. A new God-image thus emerges from the unconscious concentrations of libido, which speaks in a language appropriate to its time. Indeed, a symbol can only be called religious, according to Spiegelberg, 'insofar as this Unconscious world is reflected 
and considered in conscious thought' (1948:33). The ensuing symbol, speaking a language more appropriate to its time, therefore establishes the religious life 'on a much deeper plane'(1948:33). Eventually, however, this symbol will also inevitably become outworn, and the cycle will repeat itself.

\section{JUNG AND THE RELIGION OF NO RELIGION}

Spiegelberg's theory of the decay of religious symbols and their rebirth from the unconscious was based on his reading of Jung. In Psychological Types (1921), Jung had discussed the 'relativity of God', which he defined as the 'reciprocal and essential relation between man and God, whereby man can be understood as a function of God, and God as a psychological function of man' (1921:243). For Jung, religious symbols and dogmas could be traced to original psychic experiences, which could only be represented imperfectly in propositions of faith. Such original experiences were, in turn, only conditioned expressions of a universal, archetypal psychic state. Jung's notions on the psychological process of symbol-formation therefore parallel those in Spiegelberg's Religion of no Religion. This is evident, for example, in the following passage in Psychological Types:

The God-image is the symbolic expression of a particular psychic state, or function, which is characterised by its absolute ascendency over the will of the subject...An accumulation of energy in the unconscious... activates images lying dormant in the collective unconscious, among them the God-image, that engram or imprint which from the beginning of time has been the collective expression of the most overwhelmingly powerful influences exerted on the conscious mind by unconscious concentrations of libido. (Jung 1921:243).

The cyclical process of the religious imagination espoused in The Religion of no Religion is also indebted to Jung. The notion we encounter in Spiegelberg's work, namely that, over time, religious symbols no longer adequately express the original experience to which they point, are overthrown and reborn, was pre-empted by Jung. According to Jung, symbols lose their 'rightness' when the unconscious produces shades of meaning 'which are no longer adequately expressed by, or are at variance with, the traditional symbol' (Jung 1944:127). As soon 
as this happens, God ceases to be the overwhelming psychic factor and 'dwindles into a mere name' (Jung 1938:81). For this reason, Jung wrote, the Gods of antiquity lost their effect on the human soul. They had 'served their time and a new mystery began' (Jung 1938:81). Modern emphasis on science and rationality, he thought, would necessarily entail a turning point in religious understanding. In his 1928 publication, On Psychic Energy, Jung emphasised the necessity, for some individals, of breaking free from attachment to outworn symbolic forms:

We moderns are faced with the necessity of rediscovering the life of the spirit; we must experience it anew for ourselves. For a long time and for the great majority of mankind the symbol of a collective religion will suffice. It is perhaps only temporarily and for relatively few individuals that the existing collective religions have become inadequate. Wherever the cultural process is moving forward, whether in single individuals or in groups, we find a shaking off of collective beliefs. (1928:59).

Jung's ideas on symbol-formation can, in turn, be traced back to his self-experimentations, beginning in 1913. His later publications, quoted above, conceptualised notions he had first intuited in his visions, expressing them in scientific terminology. In a vision of 1913, for example, Jung intuited the truth of two principles that became vital notions for Spiegelberg. He perceived the underlying, common ground of all religions. In the same vision, he noted how new religious forms always derive their efficacy by responding to meanings ignored by previous religious forms. Jung recorded his intuition as follows, 'it is a worldly error to believe that religions differ in their inmost essence. Strictly speaking, it's always one and the same religion. Every subsequent form of religion is the meaning of the antecedent' (Jung 1914:112). In another vision, on the 28th of April 1917, the image of a skeleton of a prehistoric elephant weighs heavily on Jung's mind. Soon after, a serpent appears, claiming to have been a companion of Atmaviktu ${ }^{27}$ for many thousands of years. Jung's soul asks the serpent for an interpretation of the skeleton, to which it responds,

\footnotetext{
27 The figure of Atmavictu seems to emerge in Jung's fantasies in 1917, a similar time to when his notion of the Self first emerged. Indeed, the name perhaps refers to the notion of atman (the self) in Indian philosophy, which Jung had been studying contemporaneously through Max Muller's translations of the Sacred Books of the East (1883-87). Atmavictu is depicted in Images 117, 119 and 123 in the calligraphic version of Liber Novus. In 1920, Jung carved two images of Atmavictu out of thin branches which he later reproduced in stone (see The Art of C.G. Jung:148-150).
} 
The history of men and Gods, necessary errors that once lived and still obscure the view. An old hoe, useful for cultivation, not a plough that quickly turns to soil ... what is past is always an obstacle for what is to come. It must be completely cleared away. What time could not destroy must be artificially destroyed. For this you need the means that mankind has always needed to arrive at the future from the past: namely severing, seperating the old, destruction of the bones. It is truly an injury of the old, but the new live only through completely wearing out the old. Only with unnatural means can man get out of what was natural of old and hence arrive at a new naturalness. (Jung 1917:294).

Another central vision in the Black Books that demonstrates Jung's conceptual affinity with Spiegelberg's Religion of no Religion concerns the regeneration and rebirth of Izdubar, Jung's inner God. Indeed, Jung's fantasy can be read as a symbolic representation of Spiegelberg's religion of no religion. The vision proceeds as follows: Izdubar, poisoned by scientific knowledge, becomes sick. At first, Jung's 'I' is unable to help the sick God. He soon realises, however, that since Izdubar is 'not real but a fantasy', he can carry him on his back to seek help. At this moment, Jung realises that the revitalisation of the religious impulse will require a strictly psychological interpretation of religious imagery. The Gods, he would later argue, must be understood as psychic factors, that is, 'as archetypes of the collective unconscious' (Jung 1944:17). Spiegelberg conceptualised this process as a 'psychological inversion', through which God, previously seen as an outward reality, 'becomes now an inner reality to the mind' (Spiegelberg 1948:22). Such introversion of libido would inevitably result in new names and forms for God, represented in Jung's visions by Izdubar's regeneration from an egg (1913:120). ${ }^{28}$ Although the majority of Jung's recorded visions predate his

\footnotetext{
${ }^{28}$ The image of the egg is a central feature in the Images which symbolically represent the regeneration of Izdubar (see particularly images 50, 51, 55 and 56 in the calligraphic version of Liber Novus). In The Incantations, which refer to these images, Jung wrote 'We asked earth. We asked Heaven. We asked the sea. We asked the wind. We asked the fire. We looked for you with all the peoples. We looked for you with all the kings. We looked for you with all the wise. We looked for you in our own heads and hearts. And we found you in the egg' (Jung 2013: 303). In The Psychology of the Unconscious (1912), Jung discussed the Hindu God Prajapati, often symbolised as emanating from an egg. He noted that this association symbolised 'the way of introversion', through which Prajapati 'changed into something new, the multiplicity of the world' (1912:415).
} 
interest in Zen, it is nonetheless true that Buddhism plays a significant role throughout the Black Books. The earliest appearance of the Buddha is in a vision of 1913, in which the Buddha appears seated in a circle of fire, after the images of Mary holding Christ and St Peter holding a pair of keys. In a vision of 1918, the Buddha is represented as the brother of 'Ka', Philemon's shadow. ${ }^{29}$ There are also subtle references throughout the Black Books to the Buddhist scripture. In a vision of 1923, for example, the God 'He' appears before Jung's I, asking for guidance. 'What do you call wisdom', he asks. Jung replies 'I call wisdom right action coming from right thought', a clear reference to the noble eightfold path, a cornerstone of the Buddhist Tripitaka. (Jung 1923:229). ${ }^{30}$ It is clear from Jung's commentary to his visions that the Buddha was a particularly significant as a symbol of the Self. Indeed, although both Christ and Buddha were symbols of mankind's redemption, when compared to Christ, Buddha represented a more complete individuation - 'an even higher spiritual power' (Jung 2013:562).

Although The Black Books can be construed as a personal account of Jung's own individuation, Jung nonetheless intimated that his visions were merely a particular occurrence of an ancient, archetypal process. In his commentary to the vision of Izdubar, Jung wrote, 'One used to believe that one could murder a God. But the God was saved, he forged a new axe in the fire, and plunged again into the flood of light of the East to resume his ancient cycle' (Jung 2009:296). Through Jung, therefore, Spiegelberg found an attitude towards religion and mythology that, he felt, offered a psychological framework upon which to ground his comparative method. Moreover, Jung's approach went beyond typical reductive psychoanalytic explanations of religion, offering a fresh psychological outlook that transcended the purely linguistical and historical concerns of his contemporary Orientalists. In The Religion of no Religion, Spiegelberg noted the significance of Jung's psychology on the formation of his comparative approach to religion:

\footnotetext{
${ }^{29} \mathrm{Ka}$ first appears in the Black Books in a vision on the 22nd October 1917 in Volume 7 of the Black Books. Jung explains that he was a relativisation of Philemon. In Memories, he described Ka as representing 'a kind of earth demon or metal demon' (Jung 1961: 209).

${ }^{30}$ The Tripitaka (literally 'Three Baskets') is a traditional term for the collection of classical Buddhist scriptures. The Buddha set out his teaching of the Noble Eightfold Path which was recorded in various texts in the canon. For example, in the Sariputta Sutta, Buddha declares: 'This noble eightfold path-right view, right resolve, right speech, right action, right livelihood, right effort, right mindfulness, right concentration - is the stream' (Thanissaro Bhikku 2017: 692). Jung owned a copy of T.W. Rhys Davids' translation of the Buddha's sermons in Müller's Sacred Books of the East, volume 17.
} 
The affiliation with Jung and many of his fine followers has backed up my theological studies in a way I suppose that at the time made them unique, because theology was the property of the Church, where I did not belong. Indology was the property of Sanskrit departments of Indo-European linguistics, in which I was very little interested. But the psychological backing from the Jung side brought these other approaches to life. (Spiegelberg 1938:13).

In addition to his personal acquaintance with Jung and his reading of his works, Spiegelberg's Religion of no Religion was indebted to other scholars who accepted and promoted Jung's psychological approach to the study of the history of religion. His participation as an audience member at the Eranos conferences in Ascona is particularly relevant in this regard. ${ }^{31}$ Here, Jung's psychology of the religion was adopted by scholars such as Heinrich Zimmer, Jakob Hauer and Gustav Heyer as their primary interpretative framework in debating the origins of religious symbolism. It is not incidental that Spiegelberg's Religion of no Religion was first published the year after his final participation at Eranos. Spiegelberg's Religion of no Religion, therefore, was based on notions regarding the religious imgination popular at Eranos in the 1930s, which, in turn, were predicated on Jung's psychology. ${ }^{32}$ In the 1934 Eranos conference, for example, Hauer put forward a theory of the religious imagination that paralleled Spiegelberg's:

The way symbols are born also gives us a pointer to what their meaning is .... Their pictorial material mostly comes from intuition, in that a deep inner movement links us with

\footnotetext{
31 The Eranos conferences were yearly conferences, beginning in 1933, which took place in Ascona, Switerland. Their goal was to provide what the historian Hans Hakl calls 'a meeting place between East and West' (Hakl 2003: 12). Jung was actively involved int he organisation of the conferneces. More information on Jung's involvement at Eranos can be found in Hans Hakl's Eranos (2003) and Riccardo Bernardini's Jung a Eranos (2011).

${ }^{32}$ Although Jung took care to ensure that his psychology wouldn't overtake the intellectual climate at Eranos, it is undoubtedly true that almost all scholars who attended the conferences were either sympathetic to Jung's psychology, or explicitly based their own thought on their reading of Jung. Mircea Eliade, for example, called Jung the 'spiritus rector' of Eranos, (1989:xiii) while Joseph Campbell wrote that Jung's psychology offered Eranos scholars 'a new language' with which to express the concepts of Eastern religion and mythology (1960:1).
} 
an apparition which essentially vibrates and expresses what we experience in the depths of our soul. In this way this inner movement and the symbol are linked; this experience sinks into the unconscious and rises again, transformed by a secret alchemy. This is what I call the birth of the symbol ... The birth takes place when our soul is gripped by a life movement related to the one that once pulled the symbol we are looking at into the depths of our soul and interweaves it there with our whole unfounded being, so that it can now flow into us as a newly given picture ... A secret connecting thread runs through all these symbols and following it we grasp the overall harmonics of experience and knowledge of the self. (Hauer 1934:61).

The psychologist G. R. Heyer, who studied under Jung in the mid 1920 s and lecture at Eranos in the same year, echoed Hauer's interpretation. Heyer had an interest in Yoga, and his book Der Organismus der Seele (1932), an introduction to yoga from the point of view of depth psychology, was widely read during the first half of the twentieth century. In his 1934 Eranos lecture, he remarked that the evolution of religious symbolism follows an archetypal process. 'Through the power of customs, forms and guides', he observed, 'the institutions, the canon, were created from the voices of many religious people ... Again and again, when these forms are frozen, the institutions have lost their strength, the drink at the spring (i.e. the unconscious) has to renew the magic' (Heyer 1934:21). Similarly, in the 1933 Eranos conference, Heinrich Zimmer argued that 'the great symbols of other times and places ... are a picture-writing that summons us to capture a reality that has always been present, in ourselves as in the men of the past, and to live by it in new images and concepts, if the picture writing of our own tradition has either become meaningless to us, or as a metaphoric as that of other vanishing historical eras' (Zimmer 1933:28).

\section{ZEN: THE PROTOTYPE OF THE RELIGION OF NO RELIGION}

Suzuki's writings convinced Spiegelberg that Zen Buddhism held a unique place among the history of religions. Most world religions, he claimed, unconscious of their own relativity, confused their symbols with the underlying, universally accessible, mystical experience to which they had originally referred. Zen Buddhists, on the other hand, having long ago perceived the unconscious as the origin of all religious forms and symbols, 
had understood, and therefore transcended, the psychological need for particularsymbols and religious forms. Consequently, unlike other religions, Zen refused to interpret its own religious ideas and actions as ultimate truths. It was a religion, in other words, that claimed not to be a religion, since it had uncovered, in Spiegelberg's words, 'the basic principle of this need [for religion] and laughs at all the attempts of mankind to formulate the highest truth in terms of our language or even in thoughts and ideas' (Spiegelberg 1948:25). This explained the humorous iconoclasm often exemplified in Zen poetry and art, such as in Liang Kai's (1140-1210) painting of a Zen monk tearing Buddhist scriptures, or in the following Zen story:

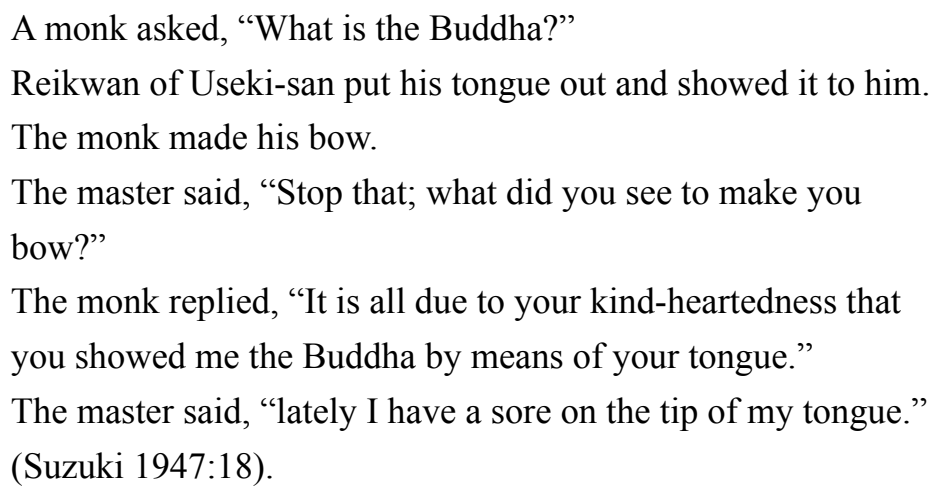

Following Suzuki, Spiegelberg interpreted satori, enlightenment, as free from any particular institutional religious form. It did not involve a change in the content of religious experience, but only a change in the way one experienced it. It was presented as an essentially natural, spontaneous and universally accessible breakthrough into consciousness of the divine, such as Spiegelberg had himself experienced during his own moment of mystical insight in 1917. Ordinary everydayness, he argued, when seen from a certain perspective, was always imbued with mystery. The search for grand spiritual truths, ideals or states of mind were simply further obstacles hindering the perception of the inherent mystery of being. Watts, in his Beyond Theology, exemplified this point, recounting the story of the Zen master Bokuju, who was asked, "We have to dress and eat every day, and how do we escape from these chores?" He answered, "We dress; we eat." But the inquirer replied, "I don't get the point." "If you don't get it," said Bokuju, "put on your clothes and eat your food" (Watts 1964:120).

Such statements could easily be mistaken as secularism or positivism. On the contrary, Spiegelberg and Watts understood Zen to be a highly spiritual tradition precisely because, through understanding the relativity 
of religious symbols, it transcended typical religious sectarianism and focused its attention directly towards the deeper transcendental source of all religious life. Again, they saw this principle reflected in seemingly secular representations typical of Zen art, particularly the landscape paintings of artists such as Sesshū and Zen stories of the kind that Spiegelberg quotes from Suzuki: "A Zen Master was asked "What is enlightenment?" And he answered: "Your everyday thoughts." (Spiegelberg 1948:27).

Such statements, Spiegelberg argued, were evidence that the Zen Masters had 'founded an attitude which can only be called the religion of no religion' (ibid. Quote taken from Suzuki). He baptised Zen, therefore, as 'the prototype of the religion of no religion' (1948:32), a 'super-religion', as he sometimes called it, unique in history, that represented an overcoming of all religious ideas and actions, not for the sake of mere iconoclasm, but rather, as he argued, 'for the purpose of establishing the religious life on a much deeper plane that is today called the Unconscious' (1948:63). He recognised that similar attempts had been made in the West by figures such as Meister Eckhart and Ralph Waldo Emerson, both of whom sought to overcome conventional religious forms, names and ceremonies, while retaining the essence of religiosity. Yet they failed, in his view, to establish a 'religion of no religion', as Zen had done, since they merely replaced old names and forms for God with new ones of their own devising. Zen, on the other hand, 'took the final step by overcoming forms as such, which are all hinderances on the way to a realization of Truth' (1948:25). In 1972, Watts summarised this unique interpretation of Zen as follows,

Zen Buddhism fascinates Westerners because its way of teaching is quite unlike that of any other religion, if religion it is. It has no dogma, requires no particular belief, and neither deals in abstractions nor harps on morality. Then what, of religion or philosophy, is left? All and nothing, for Zen deals with realitythe universe - as it is, and not as it is thought about and described. The heart of Zen is not an idea but an experience, and when that experience happens (and "happens" is just the right word) you are set free from ideas altogether. Certainly, you can still use them, but you no longer take them seriously. (Watts 1972:339). 


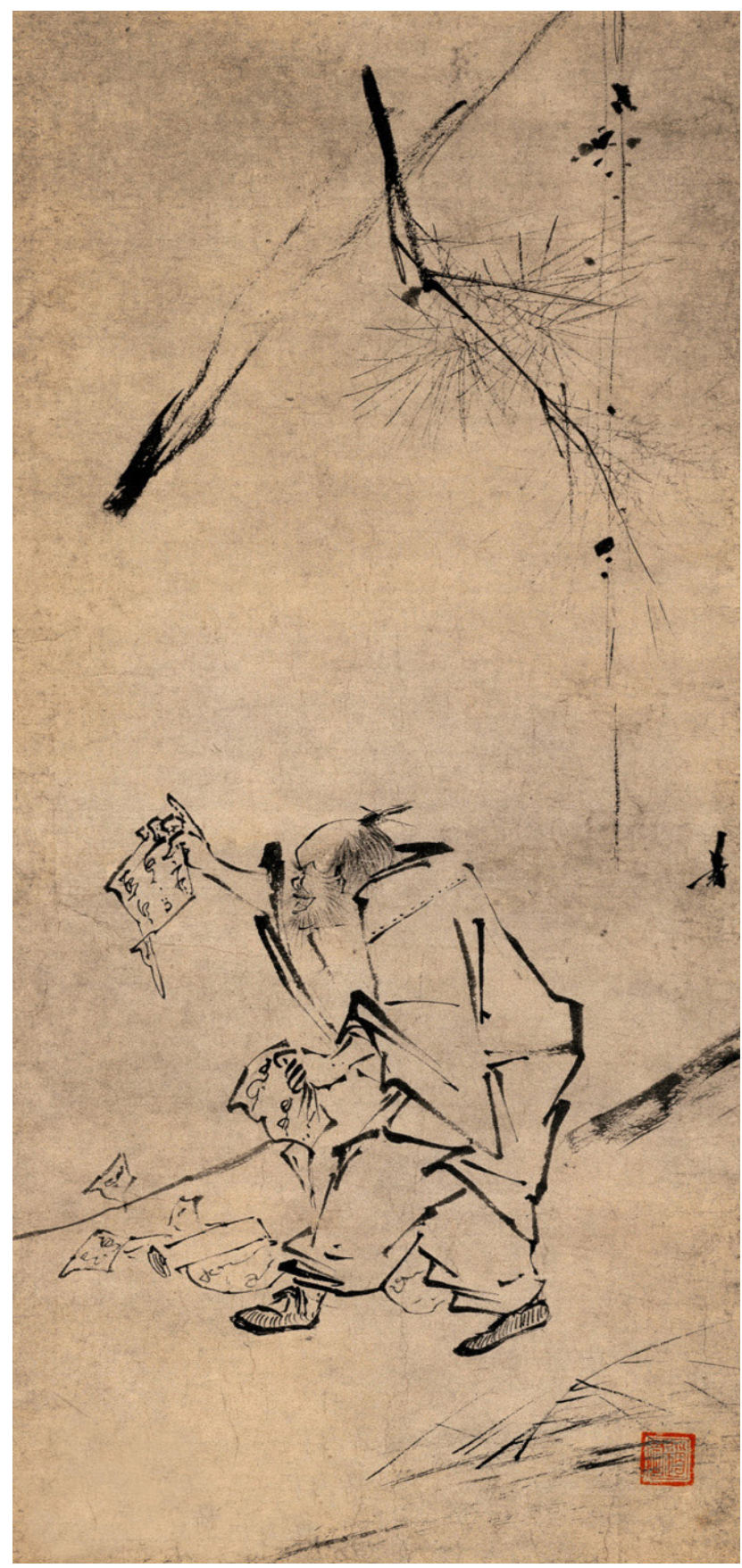

Liang K'ai-The Sixth Patriarch Tearing Buddhist Sutras 


\section{ZEN IN THE AMERICAN COUNTERCULTURE}

Zen, as represented by Suzuki, Spiegelberg and Watts, became the most popular form of Buddhism in the United States and Europe in the 1960s and 70s. Poets and writers of the American counterculture, such as Gary Snyder, Allen Ginsberg, Phil Whalen and Jack Kerouac, cultivated interest in Zen in the popular imagination. ${ }^{33}$ At the same time, Zen inspired the formation of the approaches of contemporary psychoanalysts such as Karen Horney, Wilfred Bion, Fritz Perls and Eric Fromm, to name just a few. ${ }^{34}$

The seeds of this fascination with Zen can be traced to 1951, when Spiegelberg, returning from his travels in India, was recruited as Director of Studies at the newly founded American Academy of Asian Studies, a private educational institution in California. Spiegelberg recruited Watts, who had just left his ministerial position as an Anglican priest, ${ }^{35}$ as the principal lecturer and Dean of the Academy. For Watts, Spiegelberg's invitation was a turning point in his career, the moment he reached, in his own words, 'the place where my interior compass was aimed' (Watts 1972:110). The Academy's aim was primarily to specialise in the scholarly study of Asian languages, religions and cultures, while occasionally offering some more syncretic courses on comparative religion and psychology. Soon enough, however, its founders realised that the Academy 'was at cross purposes with itself' (Watts 1972:232). The true interest of its students lay in understanding the spiritual dimension of Eastern religions, as Watts noted, 'on the level of high mysticism' (Watts 1972:232). Unsurprisingly, Spiegelberg and Watts promoted Zen, the 'prototype of the religion of no religion', as the height of spiritual attainment, the truest expression of mystical experience. Indeed, Zen was portrayed not as a religion, but as a form of psychotherapy. In April 1955, Watts taught a course entitled 'Depth Philosophy', in which he proposed the similarities between Buddhism and Jungian psychotherapy. The invitation brochure read:

\footnotetext{
${ }^{33}$ For the role of the so-called 'Beat Poets' in popularising Zen, see Rick Field's How the Swans Cam to the Lake (1993).

${ }^{34}$ For Horney and Fromm's involvement with Zen, see Zoltan Morvay's 'Horney, Zen and the Real Self' (1998). A recently published article by Yichi Zhang, entitled 'Wilfred Bion's Annotations in The Way of Zen' (2019) in Psychoanalysis and History, details Bion's interest in the work of Watts.

${ }^{35}$ An autobiographical account of Watts's years as an Episcopal priest can be found in his In My Own Way (1972).
} 
In the cultures of Asia there are various forms of 'psychotherapy,' such as Zen Buddhism, which suggest that conflicts and disorders of the mind arise from confused premises of thinking rather than repressed emotional experiences. (Watts 1955:1).

Largely due to Spiegelberg's reputation at Stanford, the Academy attracted highly intelligent, creative students, all of whom were searching for alternatives to traditional spiritual models. When his Stanford students came to him with questions regarding the practical applications of Eastern texts, Spiegelberg would point them in the direction of the Academy. 'In retrospect', Watts remarked, 'one can see that the Academy of Asian Studies was a transitional institution emerging from the failure of universities and churches to satisfy important spiritual needs' (1972:258). Among its students were figures who would later become some of the most famous artists of their generation, including Allen Ginsberg, Jack Kerouac, Lawrence Ferlinghetti, Gary Snyder and Michael McClure, all of whom were attending Watts's lectures and would later weave Zen themes into their writing. ${ }^{36}$ In Synder's Pine Tree Tops, for example, we hear echoes of Suzuki's idea of profound simplicity, and Watts and Spiegelberg's association of Zen and artistic representations of the natural world.

$$
\begin{gathered}
\text { In the blue night } \\
\text { frost haze, the sky glows } \\
\text { with the moon } \\
\text { pine tree tops } \\
\text { bend snow-blue, fade } \\
\text { into sky, frost, starlight. } \\
\text { The creak of boots. } \\
\text { Rabbit tracks, deer tracks, } \\
\text { what do we know. }
\end{gathered}
$$

(Snyder 1974)

During the years that the Academy was expanding its reach, two notable works, namely Watts's The Way of Zen (1957) and Spiegelberg's third edition of The Religion of no Religion (1952) were published. Both

\footnotetext{
${ }^{36}$ The most famous example is Jack Kerouac's Dharma Bums (1958), which introduces Watts under the pseudonym 'Arthur Wayne'. Kerouac was also attracted by the Zen tradition of haiku poetry. For more on Kerouac's Zen, see Sarah Haynes, 'An Exploration of Jack Kerouac's Buddhism: Text and Life' (2005) in Contemporary Buddhism.
} 
books became popular among the American counterculture. In 1959, Watts's began educational television lectures on Zen in San Francisco, in addition to his already popular radio shows for the radio station KPFA in Berkeley and Los Angeles. During this period, Watts's own teaching style shifted, moving from previously formal lectures to informal seminars inspired by his time in Zurich with Jung. In 1958, Watts was invited to the Jung Institute in Zurich, before travelling to Kusnacht to meet Jung. On his return, he adopted Jung's technique of the informal seminar group (Watts 1972:294).

In 1960, two of the Academy's students, Richard Price and Michael Murphy, inspired mainly by Watts and Spiegelberg's distinctive brand of Zen Buddhism, began working on plans to found a similar institute in Big Sur, California, dedicated to Buddhist meditation. Like the Academy, their institute would seek to synthesise the common insight of Eastern and Western religion and art. ${ }^{37}$ They spoke to Watts and Spiegelberg, who took an interest in their project, offered suggestions, and agreed to give seminars at their institute. In 1962, Watts led the institute's first seminar. This marked the foundation of what later became known as the Esalen Institute, which is today renowned as the birthplace of a host of new psychological notions, movements and practices that today have become mainstream. ${ }^{38}$ What was particular to Esalen's approach was its attempt to integrate supposed Zen Buddhist principles into their therapeutic practices.

The historian Jeffrey Kripal has provided a detailed history of the formation of various psychologies, worldviews, and political movements at Esalen. A discussion of these topics would deviate from the subject of this article. Suffice it to say, that Esalen was a crucial juncture in the history of Buddhism in the West, since it represented the beginning of the introduction of Buddhism's confluence with mainstream western psychological notions. What is not often recognised, however, is that Esalen was born out of the crucible of Watts and Spiegelberg's Academy of Asian Studies and inherited those authors' notions both about Zen and

\footnotetext{
${ }^{37}$ Another major inspiration for the institute was the yearly Eranos conferences, held in Ascona, whose aim was to act as the 'meeting place of East and West'. Murphy himself claime, 'Eranos and Esalen belong to the same universe of discourse, one which aims at the healing of the separation between East and West, religion and science, and body and soul. This constellation of people, ideas and practices represents a dynamic coalescence of fundamental possibilities for human transformation and advance' (Dunbar 2004:31). Jung played a large part in the organisation at Eranos, and his psychology directed the intellectual climate there. (Hakl 2003: 13)

${ }^{38}$ Esalen spawned the New Age Movement, Psychedelic Movement and Human Potential Movement of the 1970s and 80s. Gestalt Therapy and the Transpersonal Psychology of figures such as Stanislav Grof also iringated at Esalen. A detailed history of these movements can be found in Jeffrey Kripal's Esalen (2007).
} 
about the psychology of the religious imagination in general.

\section{CONCLUDING REMARKS}

The writings and lectures of Spiegelberg and Watts formed a vital juncture in the history of Zen in the West. Their interpretations, which synthesised D.T. Suzuki's portrayal of Zen with Jung's psychology of the religious imagination, have transformed and coloured the way we understand Zen today. Through their work, Zen became understood as a unique spiritual tradition that understood the universal architechtonics underlying the psyche's urge for religious symbols, while, at the same time, bypassing the category of religion altogether. Zen art and literature, they claimed, embodied the essence of the religious imagination across cultures and traditions. Although this understanding of Zen Buddhism is still today entrenched in the popular imagination, it is interesting to contrast it to what Zen scholar Robert Scharf calls 'the lived contingencies of Zen monastic practice' which, far from being iconoclastic and transhistorical, ranks among the 'most ritualistic forms of Buddhist monasticism'. Zen enlightenment, he argues, is in fact 'constituted in elaborately choreographed and eminently public ritual performances' (Scharf 1993:108). Nevertheless, the Zen Buddhism that has become familiar to many in the West, however far it has deviated from its traditional roots, belongs to its own complex history that has only recently begun to be studied.

University College London ok62923@gmail.com

\section{REFERENCES}

The Art of C.G. Jung. 2019. Edited by the Foundation of the Works of C.G. Jung. Ulrich Hoerni, Thomas Fischer, Bettina Kaufmann. Translated from German by Paul David Young and Christopher John Murray. New York and London: W.W. Norton \& Company.

Bernardini, Riccardo. 2011. Jung a Eranos. Milan: Franco Angeli.

Campbell, Joseph. 1957-68. Papers from the Eranos Yearbook, vols 1-6, Princeton, NJ: Princeton University Press.

Dunbar, Dirk. 2004. 'Eranos, Esalen, and the Ecocentric Psyche: From 
Archetype to Zeitgeist.' The Trumpeter 20(1).

Edwards, Ian Charles. 2006. Truth as Relationship: The Psychology of E. Graham Howe. PhD diss. Duquense University.

Eliade, Mircea. 1989. Journal II, 1957-69. Chicago: University of Chicago Press.

Fields, Rick. How the Swans Came to the Lake. Boulder: CO, Shambhala.

Gethin, Rupert. 1998. The Foundations of Buddhism. Oxford: Oxford University Press.

Hakl, Hans. 2013. Eranos: An Alternative Intellectual History of the Twentieth Century. Sheffield: Equinox Publishing Ltd.

Hauer, Jakob. 1934. 'Symbol and Experience of the Self in Indo-Aryan Mysticism.' Eranos Jahrbuch 1934, ed. O. Fröbe, Zurich: Rhein Verlag.

Haynes, Sarah. 2005. 'An Exploration of Jack Kerouac's Buddhism: Text and Life.' Contemporary Buddhism 6(2).

Heyer, Gustav. 1932. Der Organismus der Seele. Berlin: J.F. Lehmanns Verlag.

- 1933. 'Sinn und Bedeutung östlicher Weisheit fur die abendlandische Seelenfuhrung.' Eranos Jahrbuch 1933, vol. 1, ed. O. Fröbe, Zurich: Rhein-Verlag.

Jung, C.G. [1904]. The Associations of Normal Subjects. Collected Works of C.G.Jung. vol.2, $\S \S 3-197$.

- [1928]. On Psychic Energy. Collected Works of C.G.Jung. vol. $8, \S 3-66$.

. [1935]. Psychological Commentary on the Tibetan Book of the Dead. Collected Works of C.G.Jung. vol. 11, §§509-526.

1937-39. Letters to Alan Watts, C.G.Jung Papers Collection, ETH Zurich University Archives, HS 1056:6468, 1; 1056:8750, 1: 1056:25029, 1.

1938-40. Psychology of Yoga and Meditation: Lectures Delivered at ETH Zurich, Volume 6: 1938-1940. Edited by Martin Liebscher, translated by Heather McCartney and John Peck. New York: Princeton University Press.

. [1939]a. Foreword to Suzuki's Introduction to Zen Buddhism. Collected Works of C.G.Jung. vol. 11, §§538-557. 
[1939]b. Psychology and Religion. Collected Works of C.G.Jung. vol. $11, \S \S 64-106$.

[1944]. Psychology and Alchemy. Collected Works of C.G.Jung. vol. $12, \S \S 242-287$.

1947-57. Letters to Frederic Spiegelberg, C.G. Jung Papers Collection, ETH Zurich University Archives, HS 1056:26572, 1; 1056:26573, 1: 1056:5276, 1.

[1955]a. On the Discourses fo the Buddha. Collected Works of C.G.Jung. vol. 18, §§697-699.

[1955]b. Psychological Commentary on the Tibetan Book of the Great Liberation. Collected Works of C.G.Jung. vol. 11, §§475-508.

1961. Memories, Dreams, Reflections. London: William Collins.

2009. The Red Book: Liber Novus. Edited and with an Introduction by Sonu Shamdasani. Trans. by Mark Kyburz, John Peck, and Sonu Shamdasani. London: W.W. Norton \& Company.

. 2020. Black Books. 1913-1932. Notebooks of Transformation. Edited by Sonu Shamdasani, translated by Martin Liebscher, John Peck and Sonu Shamdasani, vols. 1-6. New York: W. W. Norton \& Company.

Jung, C.G. and Shin'ichi Hisamatsu. 1968. 'On the Unconscious, the Self and Therapy: A Dialogue.' Psychologia 11(1-2):25-32.

Kripal, Jeffrey. 2007. Esalen: America and the Religion of no Religion. Chicago: University of Chicago Press.

Morvay, Zoltan. 1999. 'Horney, Zen, and the Real Self: Theoretical and Historical Connections.' The American Journal of Psychoanalysis 59: 25-35.

Scharf, Robert. 1993. 'The Zen of Japanese Nationalism.' In Donald Lopez (ed.) Curators of the Buddha. London: University of Chicago Press.

Shamdasani, Sonu. 2020. 'Towards a Visionary Science: Jung's Notebooks of Transformation.' In C.G. Jung. 2020. Black Books. 1913-1932. Notebooks of Transformation. Edited by Sonu Shamdasani, translated by Martin Liebscher, John Peck and Sonu Shamdasani, vols. 1-6. New York: W. W. Norton \& Company.

Snyder, Gary. 1974. Turtle Island. Cambridge: MA. A New Directions Books.

Spiegelberg, Frederic. 1945. Alchemy as a Way of Salvation. Stanford 
University, CF, J. L. Delkin.

Spiegelberg, Frederic. 1948. The Religion of no-Religion. Stanford University CF, J. L. Delkin.

Spiegelberg, Frederic. 1947-57. Letters to C.G.Jung, C.G. Jung Papers Collection, ETH Zurich University Archives, HS1056:14016, 1; 1056:24354, 1.

Suzuki, Teitaro 'Daisetz'. 1927. Essays in Zen Buddhism (First Series), New York: Grove Press.

1949. Living By Zen. Newburyport, MA: Red Wheel/Weiser.

Victoria, Brian. 1997. Zen at War. New York, Rowan \& Little Publishers.

Watts, Alan. 1937. The Legacy of Asia and Western Man. London: John Murray.

Watts, Alan. 1940. The Meaning of Happiness. London. The Anchor Press Ltd.

Watts, Alan. 1955. 'Depth Philosophy' in American Academy of Asian Studies-Course List, Frederic Spiegelberg Archives, Stanford: CA; 'Professional Papers 1927-1994, Box 1, Folder 2.

Watts, Alan. 1964. Beyond Theology. New York: Pantheon Books.

Watts, Alan. 1972. In My Own Way. Novato, CF: New World Library.

Watts, Alan. 1986. 'The Mindless Scholar.' In Abe Masao (ed.) A Zen Life: D.T. Suzuki Remembered. New York: Sophia University.

Watts, Alan. 2018. The Collected Letters of Alan Watts, Joan Watts and Anne Watts (eds.), Novato: CA, New World Library.

Zimmer, 1933. 'Zur Bedeutung des indischen Tantra-Yoga.' Eranos Jahrbuch 1933, ed. O. Fröbe, Zurich: Rhein-Verlag: 5-57.

Zhang, Yichi. 2019. 'Wilfred Bion's Annotations in The Way of Zen: An Investigation into His Practical Encounters with Buddhist Ideas.' Psychoanalysis and History 21 (3):331-355.

\section{IMAGES}

K'ai, Liang. The Sixth Patriarch Tearing a Sutra. c.1140-1210. Mitsu Memorial Museum, Japan. Original file (648 x 1,492 pixels). Licensed 
under the Creative Commons Act: //commons.wikimedia.org/wiki/ File:The_Sixth_Patriarch_Tearing_a_Sutra.jpg. 